\title{
Leadership Representation of Jokowi Post-Presidential Election in Indonesia
}

\author{
Cecep Darmawan ${ }^{1}$, Heni Nuraeni Zaenudin ${ }^{2}$ \\ \{cecepdarmawan@upi.edu ${ }^{1}$, heni.nuraeni@upi.edu ${ }^{2}$ \} \\ Indonesia University of Education, J1. Dr. Setiabudi No. 229, Kota Bandung, Jawa Barat, Indonesia
}

\begin{abstract}
The administration of Joko Widodo is coming to its first year of the second period. Investigating his leadership is a potential issue as he is a Javanese. Furthermore, it is also regarded with and his idea to move the capital to East Borneo stating the end of the Java-centred era. This also leads to the end of structural authority in Java Island. The decision of Jokowi regarding this issue is based on technical-economical consideration and prosperity equality. Besides, Jokowi's interaction and communication style at the State Palace gradually reduces its sacredness which was initially too formal. Every so often, his leadership can decrease political tension. Therefore, this study attempts to investigate Jokowi's leadership representation in his second period of service. The method used in this study is discourse analysis. The results showed that Jokowi is devising an Indonesiacentred leadership style. It is particularly reflected by the development of east Indonesia which had previously never been prioritized. His figure attached by simplicity and warmth has attracted people's attention to get closer to him as he successfully conveyed his messages through media.
\end{abstract}

Keywords: representation, leadership, Joko Widodo, media, Indonesia

\section{Introduction}

In 2018, Joko Widodo announced that he was running for the second term of his presidency. In his campaign, he emphasized his political standpoint to lead Indonesia with its natural and human resource advantages. Joko Widodo embodies the trisakti (a philosophical thought introduced by Soekarno) with Indonesia's political and economic sovereignty while consistently upholding its national identity.

Joko Widodo has a pragmatic leadership style. A down-to-earth attitude is portrayed by doing blusukan (a Javanese term for impromptu visits) or going directly to discuss and find solutions. The New York Times describes Joko Widodo's leadership style as street democracy. Jokowi maintains his leadership style for the first to the second period. In the campaign for the 2019-2023 term, Jokowi made direct visits to Islamic religious groups such as Islamic boarding schools and asked for support from Nahdatul Ulama figures. Jokowi often uses quiz hoping that this simple approach will win over the hearts of the millennial and $\mathrm{z}$ generation as first-time voters.

During Joko Widodo's first 100 days in office, some ministers issued controversial regulations and statements. Some ministers are placed in institutions which have no relationship with their background. The cabinet line-up appointed in the second term was named the 
Advanced Indonesia Cabinet. The minister of religion, Fachrul Razi stated that he would regulate the prohibition of wearing the niqab or veil in government-owned institutions. Fachrul Razi also protested to State officials wearing cropped pants. According to the minister, this religious symbol is identical to radicalism. The phenomenon of the Covid-19 pandemic has dragged Terawan Agus Putranto (the minister of health) as an example of the man who repeatedly makes controversial statements. The first person in the ministry of health is supposed to play a significant role in communicating for Covid-19 anticipation but he simply stated that the virus would heal by itself under the sunshine in a tropical country like Indonesia.

Jokowi's leadership credibility faces challenges amid Indonesia's complex problems. Political communication and public policy experts criticize government apparatus communication styles that need improvement. Public needs clear and unambiguous information. The message conveyed must be proportional and professional substantially, especially during a crisis like Covid -19 pandemic. The leaders of the country should be able to be an oasis in the middle of the desert. Providing political communication in the form of solutions to health and economic problems.

President Joko Widodo conveyed his development vision for the next five years in fivepoint visions. The five development vision points include (1) infrastructure development, (2) human resource development, (3) inviting investment (4) bureaucratic reform, (5) using the state budget efficiently. The vision in his second period has relevance to the ideals of Jokowi and Yusuf Kalla. If the aspirations of the first volume focus on infrastructure development, his second term of service is focusing more on human resource development.

The commitment of Jokowi in his second term of service to strengthen the Corruption Eradication Commission is in question. Indonesia Corruption Watch regrets that President Joko Widodo pays no attention to public opinion. The media loudly reports public criticism coming from varied social organizations. The public questioned the consistency of the contemplations of the first term and the second term of service about strengthening the KPK institution by eradicating corruption.

The wave of student protests started from the House of Representatives, government offices, and all over the country. Demonstrations in December 2019 not only challenged the KUHP ratification as well as the revision of the KPK legislation. The student group considered that these two regulations were a requirement for prolonging political oligarchy. The national media Kompas.com launched news with the title polemic of the KPK Law and the controversy bill of a triangular drama that reported, "Jokowi firmly said that he would not issue the government regulations (Perppu) to cancel the KPK legislation.

This research entitled Joko Widodo's leadership representation after his second presidential election in Indonesia. The present research is the second product of a sustainable project. In the first research, the researchers focused on the commodification of religious and cultural identity politics of presidential candidates during political campaigns on social media. Research related to campaigns, politics, and media is interesting during the political campaign period. The issue of leadership is nothing new in academics. Political figures such as Barak Obama, Donald Trump are distinctive figures in many factors to examine. Their campaign strategy and how they use the media for manipulation in political competition.

\subsection{Problem Statement}

Based on the abovementioned narrative in the introduction, the research question is; what is the representation of Joko Widodo's leadership in Indonesian media in Indonesia after the presidential election? 


\subsection{Research Objective}

The objective of the present study is to determine Jokowi's leadership manifestation in Indonesian media after the presidential election.

\section{Methodology}

This research focuses on news about Joko Widodo's policy and leadership after being inaugurated as president in the second term. Researchers collect news from both printed and online media in Indonesia. News comparisons have been conducted since Joko Widodo issued his political policies in his first and second periods of service in 2019 to 2020. This research used three dimensions from Van Dijk; text, social cognition, and social context. Through discourse analysis, the researcher tries to examine news related to the issue as well as media criticism. Researchers examined the headlines, contents, and how the media frames or shows its ideologies in the news. The media selected were those with pro-government ideology and opposition to Joko Widodo's government. These media include Kompas, Tempo, Suara Merdeka, Tirto.id, Republika, Kumparan, Viva.com, Liputan6.com, Detik, com, Cnnindonesia.com, $d$ w.com.

The research entitled Joko Widodo's leadership representation after his second presidential election in Indonesia is follow-up research. In the preceding research, the researchers focused on the commodification of religious and cultural identity politics of presidential candidates during political campaigns on social media. Research related to campaigns, politics, and media is interesting to do during the political campaign period. The issue of leadership is nothing new in academics. Political figures such as Barak Obama, Donald Trump are distinctive figures in many factors to examine. Their campaign strategy and how they use the media for manipulation in political competition, [5], [7],[9]. In Indonesia, Joko Widodo's leadership and the recession of political policy between 2015 and 2019 have yet to take place. This is what makes researchers highlight the issue of representation of Joko Widodo's leadership as the elected president in the second term.

\section{Finding and Discussion}

\subsection{Joko Widodo's Leadership and blusukan (a Javanese term for impromptu visits) Political Approach}

An unconventional thing of Jokowi's attitude to approach the community is similar to Barack Obama's. Jokowi and Obama are among figures who are often seen hanging out at the outskirts and visiting music concerts. This method has proven to be effective in becoming a populist president. The advantage of this leadership style is that millennial groups vote in the second term presidential election. Joko Widodo was able to exploit the feelings of his people. Jokowi is good at playing the psychology of the masses; trying to identify himself as part of the people.

When campaigning in the second term, Joko Widodo used a political quiz strategy. The politics of the bicycle-giveaway quiz has proven to attract attention on social media. Millennials and Generation $\mathrm{Z}$ as first-time voters saw Joko Widodo as a down-to-earth figure. Quizzes with simple questions that anyone can answer have their own philosophical value. Jokowi gave a simple quiz to get close to the middle to lower class groups who are loyal political voters. 
The blusukan leadership style has been introduced since Joko Widodo served as the Mayor of Solo. This leadership style makes it easier for political figures to meet their citizens directly. This makes it easier for leaders to carry out the negotiation process related to the social problem. Blusukan is done to understand people's problems agreeably from the subject himself. Jokowi does not hesitate to directly observe the location of the incident regardless of the community's social status.

The act of distributing basic necessities in the midst of the Covid-19 pandemic by the president is a form of his concern for the people of DKI Jakarta and West Java. Jokowi wants to send a message of togetherness and mutual cooperation. The tradition of distributing basic necessities was not only carried out during the political campaign period. Jokowi's actions of blusukan in the midst of the Covid -19 outbreak indicates his attention to be acquainted with the community's actual condition.

Political observers of the Gerinda party and sociologists think that Jokowi's actions do not address substantial problems in society. Economic problems during a pandemic are not only experienced by people in DKI Jakarta and West Java. If the president can fix the big structure, small problems can be resolved. Blusukan action may result in doubt if the leader only goes around without any solution to the actual social problems. The public will think that the action is limited to imaging politics. President Joko Widodo is often criticized because his blusukan is considered ineffective.

Joko Widodo reintroduced the term Indonesia-Centred concept to the public. This term has gradually been interpreted as a development vision that does not focus on Java Island. In the third point of Nawa Cita, Jokowi wants to build Indonesia by strengthening rural areas to build a whole Indonesian Unitary State. During the 2018 presidential election campaign, Joko Widodo practiced statehood initiated by the palace. Representations of traditional clothes throughout Indonesia were introduced in various official events.

Former President Soeharto's government, in 32 years, had mostly developed Indonesia in the western part. Java and Sumatra's infrastructure is more sophisticated compared to that of eastern Indonesia. The accusation that Indonesia is a Javanese-dominated nation is widespread. The term has continued to evolve since the 1980s. There are three indicators to legitimate the recognition of the Java-centric issue. The first issue is transmigration; as if the people of Java would dominate islands outside Java. The second issue is the development which is concentrated in Java Island. The third is education that ignores the different local cultures and languages. There is an imposition of Javanese ethnic culture on non-Javanese communities. President Soeharto used military force approaches to silence voices criticizing government policies.

Discoursing Jokowi's leadership style is an interesting thing in which this figure is Javanese. The previous presidents selected Jakarta as the focus of his activities, but Joko Widodo chooses to celebrate religious holidays such as Eid al-Fitr in West Sumatra, Eid alAdha in South Kalimantan, Christmas in Papua, Waisak in Bali. The discourse on relocating the capital city to East Kalimantan also reannounce; a policy previously planned during President Soekarno's era. The concept of relocating the capital city to East Kalimantan gave the image that the Javanese centric symbol had ended. As a result, the structural concentration of power in Java Island will vanish. Jokowi's decision to move supremacy from Java was based on technical-economic considerations and equal wealth distribution. This reality, observed from a sociological approach, creates a horizontal structure rather than a hierarchical relationship.

Jokowi's new rhetoric-style tradition, especially at the palace, has undermined the sacred nature of the palace atmosphere which was previously seen as very rigid, formal, and full of the protocol. Various practices of Jokowi's political communication style, such as eating together at the dining table, drinking tea on the porch of the Presidential Palace, 
visiting Anjangsana and santri (Islamic student boarding school)-style to meet the elders with mass organization leaders and other figures, which Jokowi carried out, is aimed at relieving tensions among the lower class.

President Jokowi's political rhetoric style uses simple yet popular verbal and non-verbal communication. This has resulted in a better understanding of the communication style. Jokowi's humble figure and his simple language style have attracted public attention to always announce its exceptionality through social media.

In his state speech in Sentul Bogor on July 4, 2019, the elected president committed to focusing on bureaucratic reform in institutions and ministries. Joko Widodo administration has focused on efficiency and effectiveness in public services. The keyword for government bureaucratic reform is to serve the community. The bureaucratic culture that Jokowi will carry is not a priyayi-ism culture. This term refers to personal relationships between patrons and clients. The implementation of administration in Indonesia was influenced by the Dutch colonial government which required a lot of employees, causing the government bureaucracy to be less efficient. Besides, the government bureaucracy consists of a group of people who want to be served instead of serving the community. The function of the government bureaucracy has turned into a source of power and wealth for government officials. During the New Order era, this tradition gave birth to corruption, collusion, and nepotism culture.

\subsection{Joko Widodo's leadership in the Advanced Indonesia Cabinet}

The Jokowi-Maaruf Amin administration is entering its second year of service. This year is a reference for how they proved their promise during their political campaign. Even though this time is a very short period, it is deemed sufficient as an indicator of the government's solemnity to prove their commitment to solving the problem. Many observers of political communication criticize the government's fuzzy communications. The ministers in the Jokowi era frequently gave paradoxical statements and were considered blunders. If we evaluate the second-period government, it is more marked by controversial statements.

The first controversy was carried out by the Minister of Agrarian and Spatial Planning Sofyan Djalil dealing with the plan to remove building permits and analysis of environmental impacts. The background of this policy is due to many violations in processing the permit. Because the licensing process is lengthy, the cost of permits is getting more expensive. The decision was criticized for its potential environmental impact that would arise from development without heeding environmental sustainability and urban spatial planning.

The second was from the minister of religion, Fachrul Razi, who opposed the veil and cropped pants for the state civilian apparatus. Fachrul Razi became the first minister of religious affairs with a military background. Previously, religious ministerial appointments had always come from Nahdatul Ulama cadres. Many people doubt his competence in the ministry of religion. Fachrul Razi's appointment is related to the policy of de-radicalization. President Jokowi also gave a brief introduction regarding the task of religion to eradicate terrorism. One of the strategies is to provide preachers with training. This was done to prevent the spread of provocative teachings to the community through mosques. Another strategy is to make a certification for the preachers. Preachers who are allowed to carry out their $d a^{\prime}$ wah activities are only those who get certificates

Fachrul Razi discoursed to prohibit the use of the niqab from entering government agencies. According to him, the use of the niqab cannot be used as a measure of one's devotion. Furthermore, he believes that no verse requires the use of the veil. The policies that will be implemented by Fachrul Razi are related to state security in facing terrorism and deradicalization in state agencies. 
The similarity of the ministers' controversial statements indicates that government communications must be improved. The information conveyed must be proportional and professional. A policy must be based on information-based maturity considerations for public consumption. Communication privacy management theory describes communicators should have considerations about what to say and what should be kept from the public [2], [11]. One must consider and organize the messages that are produced, shared, and distributed to the public

Minister's information and narrative require improvement. Policy recommendations must be synchronized with the president, special staff, and related agencies. Previously, in the first term, the president issued presidential instruction no 9 of 2015 on managing public communication but it was not yet implemented. The effectiveness of government communication will occur if it starts with improving coordination within the cabinet. Besides, the government in the Jokowi's era must hear and accommodate people's aspiration before a policy is executed.

The third controversy is from health minister Terawan Agus Putranto who was appointed on October 23, 2019. Terawan joined Jokowi's cabinet when he was sanctioned by the honorary medical ethics council, an autonomous body of the Indonesian medical association because of his commercial practice of brainwashing methods for stroke patients. Since the Corona issue has become a framing in the media, the minister of health has often appeared to give his statement. His communication patterns have been highlighted several times and have received a lot of criticism from the public even by President Joko Widodo. The public believes that Terawan's statement regarding the handling of the coronavirus is not based on rational reason. Terawan stated that Indonesia is free from Corona while not explaining how to take steps to avoid the virus. The government cabinet in the Jokowi era was considered underestimating the spread of Covid-19 and did not have a settled health protocol. The discourse has received comments from one of the strongholds of the Prosperous Justice Party. As chairman of the DPP PKS, Mardani Ali Sera thought the state should not regulate personal affairs. The state cannot intervene too far in people's private space.

The public see the policies of Jokowi in handling problems with two different faces and even double standards. Jokowi still seems nervous and awkward when faced with Indonesia's complex problems. Jokowi is not a leader with intimidation and high coercion as in President Soekarno and Suharto. The leadership emphasizes more on providing an example in the hope that his subordinates will follow the role model automatically. His subordinates took advantage of Jokowi's leadership style by carrying out more obligations outside of the designated directions and commitments. Inevitably, internal commotion between the president and the cabinet ministers often occurs.

The term field general is a leadership style that is suitable to be juxtaposed with Jokowi. The meaning of the field general is a leader who has a high desire for the achievement of the cabinet under his power [1], [6]. But one thing that contrasts is that Jokowi is more like the one of troop category in which the leader prioritizes cooperation and does not impose his will. When viewed from the case of evaluating the performance of his cabinet, Jokowi is not a leader who has succeeded in motivating his subordinates to achieve their goals. Jokowi has the will to develop cooperation vertically but is tackled with sectorial egos and political competition. Jokowi also requests horizontal and vertical participation in the success of infrastructure development policies. To pursue his legacy, Jokowi is confronted with resilience in the internal bureaucracy. Debates with members of parliament from opposition parties are frequently occurring. Jokowi tries to accommodate and please many groups with different objectives. On the other hand, Jokowi has limitations in realizing their expectations. 


\subsection{Joko Widodo's Leadership Reflection against KPK Legislation}

In the second term of President Jokowi's era, he showed an inconstant leadership style. One of which was the decision to support the ratification of the KPK legislation. Beforehand, Jokowi made a statement during his second round of political campaigns that the KPK had to be reinforced and its budget must be increased. The promise to strengthen the KPK was stated in Jokowi's nine missions (Nawa Cita). These missions were denied and turned into a weakening the institution. The KPK's operational budget was never added during his reign.

This policy hitherto received a wave of protest initially started in the House of Representatives building which then spread to other regions. Protests do not seem to make Joko Widodo flinch to enforce government regulations to cancel the KPK legislation. The conspiracy between the ten factions in the People's Representative Council with the government then made the process of discussing the revision of the KPK legislation fast, closed, and exclusive. It is inversely proportional to a leadership style that portrays a pro-people leader. Jokowi's leadership style seems more authoritarian because he mobilizes military power to reduce the demonstrations which resulted in casualties.

Jokowi's leadership journey in the second term will be challenged by commotion not only from the opposition but also from his loyal voters. The ripples on the surface will occur because Jokowi does not fulfill his political promises. Jokowi's castration attitude and policy can be seen from the provisions on wiretapping, confiscation and searches procedure in KPK. These actions can only be carried out after the KPK has received permission from the supervisory board whose members are directly elected by the president. The position of the KPK as a central government institution and its status has shifted to become the civil apparatus. The weakening step is seen again from the selection of candidates who will lead the KPK. Many believe that the figure who will lead KPK in 2019-2023 is doubtful.

The one-year verdict on the offender of throwing sulphuric acid on KPK investigator Novel Baswedan is considered trivial. The public again asked President Jokowi's position and wished to intervene. The case is a reflection of the weak eradication of corruption efforts in Indonesia. Jokowi's support for law enforcement is considered unsatisfactory. If the review was carried out since Jokowi's administration, Jokowi's commitment to eradicating corruption began to be doubted after the decision to revise Law No. 30 of 2002 on the corruption eradication commission. Breaking the political promise to strengthen the KPK has an impact on the performance and credibility of the institution. During the Jokowi government, the KPK was at its lowest point. President Jokowi was also recorded in history as a president who tried to weaken the KPK.

Considering Jokowi's position as the number one person, he has legitimate power in solving the problem. Legitimate power is power and ability that comes from formal authority [3], [4], [8]. President Jokowi has the authority to make regulations to punish Novel Baswedan's attackers. Besides, he can also regulate the state to thwart the revision of the KPK legislation. Of course, the public hopes that Jokowi will be more insistent to lead in his second term.

Jokowi's power and leadership style is more about soft power. The public sees Jokowi trying to accommodate all aspirations and is less assertive. Therefore, it is indispensable for Jokowi to make decisions as one of his important functions in the government. The public demand is an echo that Jokowi must-hear. Building collaboration between the government and the community must be used as an indicator for finding solutions. 


\section{Conclusion}

Leadership is an important instrument in all aspects of state life in determining the direction and progress of a nation [10]. A leader is mostly defined by his expertise to influence and direct his followers. A leader must be able to manage, direct, influence, and motivate his subordinates. The achievement of state goals is strongly determined by the quality of the leadership style. Leadership style is a combination of attitudes, skills, and behaviour in leading social interaction [2]. Of all, behaviour is the most important component. It is a relatively consistent pattern of conduct that characterizes a leader. Leadership behaviour indicates a leadership style. Based on his leadership style, someone may be acknowledged as an authoritarian or democratic. This depends on his manifestation of the value of leadership in power, dignity relevant to the actual conditions.

\section{References}

[1] A. Calero Valdez, J. Kluge, \& M. Ziefle, "Elitism, trust, opinion leadership and politics in social protests in Germany," Energy Research and Social Science, vol. 43, pp. 132143, 2018.

[2] B. Farah, R. E, C. De Clercy \& G. Rowe, "Leadership succession in different types of organizations: What business and political successions may learn from each other," Leadership Quarterly, vol. 31, no. 1, 2020.

[3] D. Muchadenyika, \& J. Waiswa, "Policy, politics and leadership in slum upgrading: A comparative analysis of Harare and Kampala," Cities, vol. 82, pp. 58-67, 2018.

[4] G. Király, A. Köves, \& B. Balázs, "Contradictions between political leadership and systems thinking," Journal of Cleaner Production, vol. 140, pp. 134-143, 2017.

[5] J. Buschman, "Between Neoliberalism and Identity Politics: Academic Librarianship, Democracy and November 8, 2016," Journal of Academic Librarianship, vol. 44, no. 2, pp. 287-294, 2018.

[6] P. Naiyananont and T. Smuthranond, "Relationships between ethical climate, political behavior, ethical leadership, and job satisfaction of operational officers in a wholesale company, Bangkok Metropolitan region," Kasetsart j. soc. sci., vol. 38, no. 3, pp. 345351, 2017.

[7] R. McDermott, "Leadership and the strategic emotional manipulation of political identity: An evolutionary perspective," Leadership Quarterly, pp. 0-1, 2018.

[8] R. T. Marcy, "Leadership of socio-political vanguards: A review and future directions," Leadership Quarterly, vol. 31, no. 1, 2020.

[9] S. Y. Chen \&. O. Urminsky, "The role of causal beliefs in political identity and voting," Cognition, vol. 188, pp. 27-38, 2019.

[10] W. Qian and X. Chen, "Corporate environmental disclosure and political connection in regulatory and leadership changes: The case of China," Br. account. rev., vol. 53, no. 1, 2021.

[11] Z. H. G. C. von Rueden \& E. H. Hagen, "The evolutionary anthropology of political leadership," Leadership Quarterly, vol. 30, no. 1, pp. 59-80, 2019. 